\title{
Short communication: Outbreak of methicillin-resistant Staphylococcus aureus (MRSA)-associated mastitis in a closed dairy herd
}

\author{
F. F. Guimarães, ${ }^{1}$ M. P. Manzi, S. F. Joaquim, V. B. Richini-Pereira, and H. Langoni \\ Departamento de Higiene Veterinária e Saúde Pública, Faculdade de Medicina Veterinária e Zootecnia, UNESP-Univ. Estadual Paulista, \\ Campus de Botucatu, Distrito de Rubião Júnior s/n, Botucatu, SP 18618-970, Brazil
}

\begin{abstract}
Cows are probably the main source of contamination of raw milk with Staphylococcus aureus. Mammary glands with subclinical mastitis can shed large numbers of Staph. aureus in milk. Because of the risk of this pathogen to human health as well as animal health, the aim of this paper was to describe an outbreak of mastitis caused by methicillin-resistant Staph. aureus (MRSA), oxacillin-susceptible mecA-positive Staph. aureus (OS-MRSA), and methicillin-susceptible Staph. aureus (MSSA) on a dairy farm. Milk samples were obtained from all quarters, showing an elevated somatic cell count by the California Mastitis Test. The isolates were identified by phenotypic and genotypic methods. Staphylococcus spp. were isolated from $53 \%(61 / 115)$ of the milk samples, with 60 isolates identified as Staph. aureus (98.4\%) and 1 isolate identified as Staphylococcus epidermidis (1.6\%). The presence of the mecA gene was verified in $48.3 \%$ of Staph. aureus isolates. Of the Staph. aureus isolates, $23.3 \%$ were MRSA and $25.0 \%$ were OS-MRSA. The total of mastitis cases infected with MRSA was $12.2 \%$. The detection of this large percentage of mastitis cases caused by MRSA and OS-MRSA is of great concern for the animals' health, because $\beta$-lactams are still the most important antimicrobials used to treat mastitis. In addition, Staph. aureus isolates causing bovine mastitis represent a public health risk.
\end{abstract}

Key words: methicillin-resistant Staphylococcus aureus (MRSA), oxacillin-susceptible mecA-positive Staphylococcus aureus (OS-MRSA), mecA gene, bovine milk

\section{Short Communication}

Mastitis is a worldwide problem in dairy herds. It is the most frequent infectious disease in dairy cows,

Received July 5, 2016.

Accepted September 12, 2016.

${ }^{1}$ Corresponding author: felipefreitasguimaraes@hotmail.com accountable for great losses in dairy production. More than 100 microbial species have been isolated from the mammary glands of cows; however, a relatively small number of these organisms cause mastitis (Owens and Watts, 1988; Costa et al., 1999).

The etiological microorganisms of mastitis are generally classified as "contagious" or "environmental" based on their source, reservoir, and mode of transmission (Ruegg, 2012; Langoni, 2013). For contagious pathogens, the infected mammary glands serve as the primary source of infection, and transmission occurs mainly during the milking period when healthy quarters are exposed to droplets of infected milk or when these droplets are left on milking equipment, towels, or the hands of milkers. The term "environmental pathogens," as it relates to mastitis, refers to microorganisms that are found in a cow's surroundings such as bedding, various surfaces, and in the pasture. Excessive mud, moisture, and manure are commonly associated with these pathogens. Successful control of environmental mastitis is based on maintaining a clean and dry living area, whereas successful control of contagious mastitis is based on reducing exposure to teats contaminated with pathogens found in the milk of infected cows (Ruegg, 2012).

Staphylococcus aureus is one of the main contagious mastitis pathogens. Infected cows are probably the main source of contamination of raw milk with Staph. aureus (Jayarao et al., 2004). In particular, cows with subclinical Staph. aureus mastitis infections can shed a large number of Staph. aureus organisms in their milk. Staphylococcus aureus is an important pathogen because of a combination of toxin-mediated virulence, invasiveness, and antibiotic resistance (de Freitas Guimarães et al., 2013; Silva et al., 2014).

In addition, this bacterium is a significant cause of human nosocomial infections. The epidemiology of Staph. aureus has changed fundamentally in recent years. In particular, methicillin-resistant Staph. aureus (MRSA), which was originally restricted to hospitals, has emerged as a significant pathogen in the community (community-acquired MRSA, or CA-MRSA), considerably increasing the importance of this pathogen to 
public health as well as to animal health (Vandenesch et al., 2003).

Although Staph. aureus is a major cause of bovine mastitis, previously published reports have indicated a low prevalence of bovine MRSA, implying that MRSA is not commonly associated with mastitis (Hendriksen et al., 2008).

Methicillin-resistant Staph. aureus was first reported in cows in 1972, when Devriese and coworkers (1972) found $5.2 \%$ of Belgian cows on 232 dairy farms to be positive for MRSA. In that study, Devriese et al. (1972) recovered 18 methicillin (cloxacillin)-resistant Staph. aureus isolates in 17 of 776 cows $(2.2 \%)$, and these isolates were associated with Staph. aureus-positive milk samples. More recently, MRSA has been sporadically detected in cases of bovine mastitis (Lee, 2003).

Staphylococcus aureus is defined as MRSA when either the mecA gene is present or the oxacillin MIC is greater than $4 \mu \mathrm{g} / \mathrm{mL}$. However, Staph. aureus isolates that are positive for mecA and PBP2a but phenotypically susceptible to oxacillin have also been reported (Sakoulas et al., 2001; Saeed et al., 2010). These isolates are referred to as oxacillin-susceptible mecA-positive Staph. aureus (OS-MRSA; Pu et al., 2014).

The purpose of this study was to describe an outbreak of mastitis caused by MRSA and OS-MRSA in a dairy herd. We studied a herd of Brazilian dairy cows that was located in São Paulo State, exhibited high bulk milk SCC $(628,000$ cells $/ \mathrm{mL})$, and tested positive for clinical or subclinical mastitis. The dairy farm produced an average of $530 \mathrm{~kg}$ of milk per day. Improper milking hygiene was reported (lack of pre- and postmilking teat dipping; the California Mastitis Test (CMT) was performed only biannually, udder towels were used on more than one cow, and employees were not using gloves. A total of 103 Holstein cows were evaluated. The entire herd of lactating cows was screened using a strip cup and the CMT (Schalm and Noorlander, 1957). Mammary quarters positive by the strip cup test or CMT, or both, were aseptically sampled and stored in refrigerated isothermal boxes for transport to the laboratory for bacteriological analysis (NMC, 1999).

For the bacteriological examination, $0.01 \mathrm{~mL}$ of milk was plated onto a blood agar medium containing $5 \%$ bovine blood and MacConkey agar, and samples were applied using the streaking technique. Plates were then incubated under aerobic conditions at $37^{\circ} \mathrm{C}$ and observed after 24,48 , and $72 \mathrm{~h}$ of incubation. The samples were considered contaminated when more than 2 types of colonies were isolated from a sample. Isolates were identified based on colony morphology, Gram staining, and catalase, coagulase, and biochemical testing (NMC, 1999; de Freitas Guimarães et al., 2013). Biochemical tests performed included the following: sugar fermentation (trehalose, maltose, and mannitol) and acetoin production (Kloos and Schleifer, 1975). To confirm the identification of Staphylococcus aureus, we used the primers Staur 4 and Staur 6, which were previously described by Straub et al. (1999).

Staphylococcus DNA was extracted using an Illustra Blood GenomicPrep Mini Spin Kit (GE Healthcare, Uppsala, Sweden). The gene target was amplified with primers mecA1 (5'-AAAATCGATGGTAAAGGTTGG-3') and mecA2 (5'-AGTTCTGCAGTACCGGATTTG-3'), described by Murakami et al. (1991).

Polymerase chain reactions, used to determine resistance genes, were performed with 10 pmol of each primer, $1.0 \mathrm{U}$ of Platinum Taq DNA Polymerase (Invitrogen, Carlsbad, CA), $200 \mu M$ dNTP, $1 \times$ PCR buffer, $0.75 \mathrm{mM} \mathrm{MgCl} 2$, and $3 \mu \mathrm{L}$ of sample. Staphylococcus aureus mecA-positive (ATCC 33591) and Staphylococcus aureus mecA-negative (ATCC 25923) samples were used as controls. Incubations were carried out in a Mastercycler gradient EP thermocycler (Eppendorf, Hamburg, Germany). The cycling profile was $94^{\circ} \mathrm{C}$ for $4 \mathrm{~min}$, followed by 40 cycles of denaturation at $94^{\circ} \mathrm{C}$ for $30 \mathrm{~s}$, annealing at $55^{\circ} \mathrm{C}$ for $30 \mathrm{~s}$, and extension at $72^{\circ} \mathrm{C}$ for $1 \mathrm{~min}$, with a final extension at $72^{\circ} \mathrm{C}$ for $5 \mathrm{~min}$. The PCR products were visualized on a 1.5\% agarose gel, as described by Murakami et al. (1991).

Oxacillin MIC were determined using E-test strips (bioMérieux, Durham, NC) with a 0.5 McFarland standard inoculum on Mueller-Hinton agar plates (Remel, Lenexa, KA) according to the manufacturer's manual (EAS 003; AB Biodisk, Solna, Sweden). The MIC values were determined based on the actual endpoint, established according to the manufacturer's recommendations or by rounding up to the next highest doubling dilution, which is the approach recommended by the manufacturer for reporting results (CLSI, 2013).

Staphylococcus spp. were isolated from 61 (53\%) of the 115 CMT-positive quarter milk samples, with 60 (98.4\%) of these isolates identified as Staphylococcus aureus and 1 (1.6\%) identified as Staphylococcus epidermidis. The following other pathogens were isolated: 25 (21.7\%) Corynebacterium bovis, 5 (4.3\%) Streptococcus uberis, 3 (2.6\%) Streptococcus dysgalactiae, 3 (2.6\%) Klebsiella pneumoniae, and 1 (0.9\%) Escherichia coli, as shown in Table 1. These isolates could be classified as $74.8 \%$ contagious pathogens and $10.4 \%$ environmental pathogens.

The mecA gene was detected in $29(48.3 \%)$ of the 60 Staph. aureus isolates (Table 2). Of the Staph. aureus isolates, $14(23.3 \%)$ mecA-positive Staph. aureus expressed methicillin resistance (MRSA), 15 (25\%) of $m e c A$-positive isolates were susceptible to oxacillin (OS- 
MRSA), and 31(51.7\%) mecA-negative Staph. aureus were methicillin-susceptible (MSSA). Consequently, $12.2 \%$ of the mastitis cases were caused by MRSA.

Methicillin-resistant Staph. aureus isolates are only rarely associated with bovine mastitis. However, in spite of the other contagious and environmental bacterial species that were isolated from mastitis cases in this study, $12.2 \%$ of isolates were MRSA - a very significant finding. Our data clearly show that high-level occurrence of MRSA-infected mammary glands characterized a MRSA mastitis outbreak compared with the available literature data.

Haran et al. (2012) noted that, in the United States, limited data are available on the prevalence of MRSA in bovine milk. Previous studies have reported low to no infections with MRSA in bovine milk. Anderson et al. (2006) determined a MRSA infection rate of $0 \%$ in 357 Staph. aureus isolates from bovine milk in North Carolina and Virginia; Erskine et al. (2002) detected $0.6 \%$ MRSA in 846 Staph. aureus isolates in Michigan; and Makovec and Ruegg (2003) verified 1.8\% MRSA in 2,132 Staph. aureus isolates in Wisconsin.

Other countries have reported a range of MRSA prevalence in bovine milk: $1.4 \%$ in Switzerland (Huber et al., 2010), 1.5\% in Japan (Hata et al., 2010), 2.8\% in Korea (Moon et al., 2007), 0-7.4\% in Belgium (Vanderhaeghen et al., 2010), and 5.1-16.7\% in southwest Germany (Spohr et al., 2011). Methicillin-resistant Staph. aureus was rarely detected as a cause of bovine mastitis in Finland, and only $1.5 \%$ Staph. aureus isolates were resistant to methicillin (Gindonis et al., 2013).

It is important to point out that, among the Staph. aureus isolates from mastitis bovine cases in the dairy herd, $25 \%$ of mecA-positive isolates were susceptible to oxacillin, as determined by antimicrobial susceptibility assays, and were therefore classified as OS-MRSA.

Table 1. Pathogens isolated from milk samples collected from all mammary glands positive for subclinical mastitis (determined by California Mastitis Test) in 103 cows of one dairy herd in Botucatu, Brazil

\begin{tabular}{lcr}
\hline Microbiological diagnosis & $\begin{array}{c}\text { No. } \\
\text { diagnosed }\end{array}$ & \multicolumn{1}{c}{$\%$} \\
\hline Staphylococcus aureus $^{1}$ & 60 & 52.1 \\
Staphylococcus epidermidis $^{1}$ & 1 & 0.9 \\
Streptococcus dysgalactiae $^{1}$ & 3 & 2.6 \\
Streptococcus uberis $^{2}$ & 5 & 4.3 \\
Corynebacterium bovis $^{1}$ & 25 & 21.7 \\
Klebsiella pneumoniae $^{2}$ & 3 & 2.6 \\
Escherichia coli $^{2}$ & 1 & 0.9 \\
Contaminated $_{\text {No growth }}$ & 2 & 1.7 \\
Total & 15 & 13.0 \\
& 115 & 100.0 \\
\hline
\end{tabular}

${ }^{1}$ Contagious pathogen.

${ }^{2}$ Environmental pathogen.
Table 2. Phenotypic and genotypic resistance profiles ${ }^{1}$ of Staphylococcus aureus isolated from subclinical mastitis cases in Botucatu, Brazil

\begin{tabular}{lcc}
\hline Resistance profile & No. & $\%$ \\
\hline MRSA & 14 & 23.3 \\
MSSA & 31 & 51.7 \\
OS-MRSA & 15 & 25.0 \\
Total Staph. aureus isolates & 60 & 100.0 \\
\hline
\end{tabular}

${ }^{1} \mathrm{MRSA}=$ methicillin-resistant Staph. aureus : OS-MRSA $=$ oxacillinsusceptible mecA-positive Staph. aureus; MSSA = methicillin-susceptible Staph. aureus.

These results raise a concern: OS-MRSA would not have been detected if the genotypic analysis of these isolates had not been performed. Although OS-MRSA is susceptible to oxacillin, it may develop into highly resistant MRSA following antibiotic selection because $m e c A$ is present (Hososaka et al., 2007; Ikonomidis et al., 2008). Therefore, even when oxacillin resistance is not observed, Staph. aureus isolates carrying the mecA gene may represent a risk because of plasmidial transmission to other bacteria. Recently, Pu et al. (2014) determined that $47.6 \%$ (49 of 103) of the Staph. aureus isolates from 450 mastitic milk samples carried mecA, which was higher than the previously reported highest MRSA incidence (17.5\%; Turutoglu et al., 2006). However, just 12 of 103 of those isolates were oxacillin resistant; that is, only $11.6 \%$ of these isolates were MRSA. Therefore, OS-MRSA accounted for $35.9 \%$ (37 of 103) of the total Staph. aureus isolates, indicating a high prevalence of OS-MRSA in clinical bovine mastitis cases in China. All of the OS-MRSA isolates demonstrated an oxacillin $\mathrm{MIC}<2 \mu \mathrm{g} / \mathrm{mL}$, indicating that the presence of the mecA gene did not confer high-level resistance to oxacillin. $\mathrm{Pu}$ et al. (2014) found that OS-MRSA isolates carried the mecA gene, they were susceptible to oxacillin, and could be mistakenly identified as MSSA if testing for the mecA gene had not been conducted. Their results suggested that MRSA is more commonly associated with bovine mastitis than previously realized, at least in China. Those findings (Pu et al., 2014), along with increasing reports of OS-MRSA in clinical and subclinical mastitis cases, as presented here, indicate the need for genetic as well as phenotypic assays to accurately identify MRSA.

Methicillin-resistant Staph. aureus has seldom been detected in dairy herds. However, in this study, MRSA was associated with subclinical and clinical mastitis, and therefore should be controlled for animal health and milk quality and as a zoonosis. Equally significant was the detection of strains resistant to multiple antimicrobials administered to both animals and humans. Eradication of MRSA from a dairy herd requires identification of all potential sources and reservoirs of MRSA (Spohr et al., 2011). Our examination of this outbreak 
reinforces the need to eliminate MRSA and to control mastitis cases associated with MSSA infections. However, eradicating MRSA from a herd is not a realistic option. To effectively control contagious MRSA- and MSSA-associated mastitis in dairy herds, the general recommendation is to implement procedures to prevent the spread of bacteria mainly at the time of milking, including good udder hygiene and pre- and postmilking teat disinfection with an effective teat antiseptic. In addition, all quarters should be infused with antibiotics approved for use in nonlactating cows after the last milking of the lactation period to eliminate existing infections and prevent new infections during the early dry period, when the udder is highly susceptible to new infection. Moreover, it may be necessary to cull chronically infected cows.

Furthermore, in the current study, most of the IMI cases were caused by contagious pathogens (74.8\%); environmental pathogens accounted for only $10 \%$ of the cases. The large proportion of IMI cases caused by contagious pathogens showed that it is critical to adopt methods during milking to control an outbreak, in addition to other therapeutics and prophylactic measures. The failure to implement some important preventive measures during routine milking may have resulted in this outbreak. Specifically, pre-and postmilking teat disinfection was not performed and the hygiene of milkers' hands was poor (i.e., gloves were not used during the milking process). In past studies, Staph. aureus has been isolated from the nostrils and hands of dairy workers, which can serve as sources of mastitis infections in cows and heifers.

The identification of a large number of MRSA and OS-MRSA isolates is of great concern for the health of animals, because $\beta$-lactams the most commonly used antimicrobials to treat bovine mastitis. In addition, Staph. aureus from cases of bovine mastitis represents a public health risk.

\section{ACKNOWLEDGMENTS}

This study was funded by FAPESP (The São Paulo Research Foundation, Brazil) support research grant numbers 2008/11614-1 and 2011/21323-7 and scholarship grants numbers 2008/08780-7 and 2011/21142-2.

\section{REFERENCES}

Anderson, K. L., R. L. Lyman, S. M. Bodeis-Jones, and D. G. White. 2006. Genetic diversity and antimicrobial susceptibility profiles among mastitis-causing Staphylococcus aureus isolated from bovine milk samples. Am. J. Vet. Res. 67:1185-1191.

CLSI. 2013. Performance standards for antimicrobial susceptibility testing. CLSI approved standard M100-S23. Clinical and Laboratory Standards Institute, Wayne, PA.
Costa, E. O., A. R. Ribeiro, E. T. Watanabe, J. A. B. Silva, F. GarinoJunior, N. R. Benites, and A. M. Horiuti. 1999. Mastite subclínica: Prejuízos causados e os custos de prevenção em propriedades leiteiras. Revista Nap Gama 2:16-20.

de Freitas Guimarães, F., D. B. Nóbrega, V. B. Richini-Pereira, P. M. Marson, J. C. de Figueiredo Pantoja, and H. Langoni. 2013. Enterotoxin genes in coagulase-negative and coagulase-positive staphylococci isolated from bovine milk. J. Dairy Sci. 96:28662872.

Devriese, L. A., L. R. Van Damme, and L. Fameree. 1972. Methicillin (cloxacillin)-resistant Staphylococcus aureus strains isolated from bovine mastitis cases. Zentralbl. Veterinarmed. B 19:598-605.

Erskine, R. J., R. D. Walker, C. A. Bolin, P. C. Bartlett, and D. G. White. 2002. Trends in antibacterial susceptibility of mastitis pathogens during a seven-year period. J. Dairy Sci. 85:1111-1118.

Gindonis, V., S. Taponen, A.-M. Myllyniemi, S. Pyörälä, S. Nykäsenoja, S. Salmenlinna, L. Lindholm, and M. Rantala. 2013. Occurrence and characterization of methicillin-resistant staphylococci from bovine mastitis milk samples in Finland. Acta Vet. Scand. 55:61.

Haran, K. P., S. M. Godden, D. Boxrud, S. Jawahir, J. B. Bender, and S. Sreevatsan. 2012. Prevalence and characterization of Staphylococcus aureus, including methicillin-resistant Staphylococcus aureus, isolated from bulk tank milk from Minnesota dairy farms. J. Clin. Microbiol. 50:688-695.

Hata, E., K. Katsuda, H. Kobayashi, I. Uchida, K. Tanaka, and M. Eguchi. 2010. Genetic variation among Staphylococcus aureus strains from bovine milk and their relevance to methicillin-resistant isolates from humans. J. Clin. Microbiol. 48:2130-2139.

Hendriksen, R. S., D. J. Mevius, A. Schroeter, C. Teale, D. Meunier, P. Butaye, A. Franco, A. Utinane, A. Amado, M. Moreno, C. Greko, K. Stärk, C. Berghold, A.-L. Myllyniemi, D. Wasyl, M. Sunde, and F. M. Aarestrup. 2008. Prevalence of antimicrobial resistance among bacterial pathogens isolated from cattle in different European countries: 2002-2004. Acta Vet. Scand. 50:28.

Hososaka, Y., H. Hanaki, H. Endo, Y. Suzuki, Z. Nagasawa, Y. Otsuka, T. Nakae, and K. Sunakawa. 2007. Characterization of oxacillin-susceptible mecA-positive Staphylococcus aureus: A new type of MRSA. J. Infect. Chemother. 13:79-86.

Huber, H., S. Koller, N. Giezendanner, R. Stephan, and C. Zweifel. 2010. Prevalence and characteristics of meticillin-resistant Staphylococcus aureus in humans in contact with farm animals, in livestock, and in food of animal origin, Switzerland. Euro Surveill. 15:19542.

Ikonomidis, A., G. Michail, A. Vasdeki, M. Labrou, V. Karavasilis, C. Stathopoulos, A. N. Maniatis, and S. Poumaras. 2008. In vitro and in vivo evaluations of oxacillin efficiency against mecA-positive oxacillin-susceptible Staphylococcus aureus. Antimicrob. Agents Chemother. 52:3905-3908.

Jayarao, B. M., S. R. Pillai, A. A. Sawant, D. R. Wolfgang, and N. V. Hegde. 2004. Guidelines for monitoring bulk tank milk somatic cell and bacterial counts. J. Dairy Sci. 87:3561-3573.

Kloos, W. E., and K. H. Schleifer. 1975. Simplified scheme for routine identification of human Staphylococcus species. J. Clin. Microbiol. $1: 82-88$.

Langoni, H. 2013. Qualidade do leite: Utopia sem um programa sério de monitoramento da ocorrência de mastite bovina. Pesqui. Vet. Bras. 33:620-626.

Lee, J. H. 2003. Methicillin (oxacillin)-resistant Staphylococcus aureus strains isolated from major food animals and their potential transmission to humans. Appl. Environ. Microbiol. 69:6489-6494.

Makovec, J. A., and P. L. Ruegg. 2003. Antimicrobial resistance of bacteria isolated from dairy cow milk samples submitted for bacterial culture: 8,905 samples (1994-2001). J. Am. Vet. Med. Assoc. $222: 1582-1589$.

Moon, J.-S., A.-R. Lee, H.-M. Kang, E.-S. Lee, M.-N. Kim, Y. H. Paik, Y. H. Park, Y.-S. Joo, and H. C. Koo. 2007. Phenotypic and genetic antibiogram of methicillin-resistant staphylococci isolated from bovine mastitis in Korea. J. Dairy Sci. 90:1176-1185.

Murakami, K. W., K. Minamide, W. Wada, E. Nakamura, H. Teraoka, and S. Watanabe. 1991. Identification of methicillin resistant 
strains of staphylococci by polymerase chain reaction. J. Clin. Microbiol. 29:2240-2244.

National Mastitis Council. 1999. Laboratory Handbook on Bovine Mastitis. National Mastitis Council, Madison, WI.

Owens, W. E., and J. L. Watts. 1988. Antimicrobial susceptibility and beta-lactamase testing of staphylococci isolated from dairy herds. J. Dairy Sci. 71:1934-1939.

Pu, W., Y. Su, J. Li, C. Li, Z. Yang, H. Deng, and C. Ni. 2014. High incidence of oxacillin-Susceptible mecA-positive Staphylococcus aureus (OS-MRSA) associated with bovine mastitis in China. PLoS One 9:e88134.

Ruegg, P. L. 2012. Managing cows, milking and the environment to minimize mastitis. Adv. Dairy Technol. 24:351-359.

Saeed, K., M. Dryden, and R. Parnaby. 2010. Oxacillin-susceptible MRSA, the emerging MRSA clone in the UK? J. Hosp. Infect. $76: 267-268$.

Sakoulas, G., H. S. Gold, L. Venkataraman, P. C. DeGirolami, G. M. Eliopoulos, and Q. Qian. 2001. Methicillin-resistant Staphylococcus aureus: Comparison of susceptibility testing methods and analysis of $m e c A$-positive susceptible strains. J. Clin. Microbiol. 39:3946-3951.

Schalm, O. W., and D. O. Noorlander. 1957. Experiments and observation leading to development of California Mastitis Test. J. Am. Vet. Med. Assoc. 130:199-204.
Silva, N. C. C., F. F. Guimarães, M. P. Manzi, A. Fernandes Júnior, E. Gómez-Sanz, P. Gómez, H. Langoni, V. L. M. Rall, and C. Torres, 2014. Methicillin-resistant Staphylococcus aureus of lineage ST398 as cause of mastitis in cows. Lett. Appl. Microbiol. 59:665-669.

Spohr, M., J. Rau, A. Friedrich, G. Klittich, A. Fetsch, B. Guerra, J. A. Hammerl, and B. A. Tenhagen. 2011. Methicillin-resistant Staphylococcus aureus (MRSA) in three dairy herds in southwest, Germany. Zoonoses Public Health 58:252-261.

Straub, J. A., C. Hertel, and W. P. Hammes. 1999. A 23S RNArtargeted polymerase chain reaction-based system for detection of Staphylococcus aureus in meat started cultures and dairy products. J. Food Prot. 62:1150-1156.

Turutoglu, H., S. Ercelik, and D. Ozturk. 2006. Antibiotic resistance of Staphylococcus aureus and coagulase-negative Staphylococci isolated from bovine mastitis. Bull. Vet. Inst. Pulawy 50:41-45.

Vandenesch, F., T. Naimi, M. C. Enright, G. Lina, G. R. Nimmo, H. Heffernan, N. Liassine, M. Bes, T. Greenland, M. E. Reverdy, and J. Etienne. 2003. Community-acquired methicillin resistant Staphylococcus aureus carrying Panton-Valentine leukocidin genes: Worldwide emergence. Emerg. Infect. Dis. 9:978-984.

Vanderhaeghen, W., T. Cerpentier, C. Adriaensen, J. Vicca, K. Hermans, and P. Butaye. 2010. Methicillin-resistant Staphylococcus aureus (MRSA) ST398 associated with clinical and subclinical mastitis in Belgian cows. Vet. Microbiol. 144:166-171. 